CZASOPISMO INŻYNIERII LĄDOWEJ, ŚRODOWISKA I ARCHITEKTURY JOURNAL OF CIVIL ENGINEERING, ENVIRONMENT AND ARCHITECTURE

JCEEA, t. XXXIII, z. 63 (3/16), lipiec-wrzesień 2016, s. 255-262

\author{
Michał MARCHACZ ${ }^{1}$ \\ Antonina $\dot{\mathrm{Z}} \mathrm{ABA} \mathbf{A}^{2}$
}

\title{
PILOTAŻOWE BADANIA AKUSTYCZNE ZABYTKOWYCH KOŚCIOŁÓW DREWNIANYCH NA TERENIE GÓRNEGO ŚLĄSKA
}

\begin{abstract}
Praca przedstawia badania akustyczne wybranych zabytkowych kościołów drewnianych będących częścią materialnego dziedzictwa kulturowego. Rozpatrywane obiekty przynależą do obszarów województwa śląskiego i opolskiego. Ich umiejscowienie powiązane jest $\mathrm{z}$ dwoma górnośląskimi szlakami architektury drewnianej. Zawarte w obrębie szlaków obiekty stanowiące zabytki architektury drewnianej to nie tylko kościoły ale również chałupy, dzwonnice, kaplice, karczmy, leśniczówki, młyn wodny, skanseny, spichlerze. Rozpatrywane w artykule obiekty to kościół świętej Barbary w Strzelcach Opolskich, kościół Narodzenia Najświętszej Maryi Panny w Szałszy oraz kościół świętego Jerzego w Ostropie. Pomiary akustyczne wnętrz zostały zrealizowane w ramach szerszego cyklu prac dotyczących zagadnień związanych z eksploatacją i utrzymaniem obiektów o charakterze zabytkowym. Opracowanie zawiera, we wstępie, zarys historyczny przedstawianych obiektów wraz z krótką informacją o ich budowie. W dalszej kolejności przedstawiona została metodyka pomiarowa związana $\mathrm{z}$ wyznaczeniem czasu pogłosu wnętrz rozpatrywanych obiektów jako podstawowego parametru akustycznego charakteryzującego dane wnętrza. Zgodnie z wytycznymi normowymi przeprowadzono szereg pomiarów czasu pogłosu. Pomiary te były podstawą do opracowania charakterystyk czasu pogłosu w funkcji częstotliwości oraz wartości uśrednionych czasu pogłosu dla poszczególnych punktów pomiarowych dla każdego z wnętrz w omawianych obiektach. Przedstawione charakterystyki czasu pogłosu w funkcji częstotliwości oraz wartości uśrednione stanowiły punkt wyjścia do dalszej oceny badanych wnętrz pod kątem ich jakości akustycznej. W podsumowaniu pracy zawarto omówienie wybranych kryteriów oceny akustycznej wnętrz opracowanych na podstawie wyników pomiarów.
\end{abstract}

Słowa kluczowe: akustyka wnętrz, czas pogłosu, badania czasu pogłosu, zabytkowa architektura drewniana

\footnotetext{
${ }^{1}$ Autor do korespondencji / corresponding author: Michał Marchacz, Politechnika Śląska, Katedra Budownictwa Ogólnego i Fizyki Budowli, ul. Akademicka 5, 44-100 Gliwice; tel. 322371567; michal.marchacz@polsl.pl

2 Antonina Żaba, Politechnika Śląska, Katedra Budownictwa Ogólnego i Fizyki Budowli, ul. Akademicka 5, 44-100 Gliwice; tel. 322371567; antonina.zaba@polsl.pl
} 


\section{Wprowadzenie}

Zabytkowa architektura drewniana na terenie Górnego Śląska stanowi jeden z ciekawszych zbiorów obiektów zabytkowych stanowiących istotną część dziedzictwa kulturowego i historycznego tego regionu. Rozpatrywane obiekty rozmieszczone są przy obecnym stanie podziału administracyjnego w obrębie województwa śląskiego i opolskiego. Objęte są działaniami o charakterze popularyzatorskim, którego przejawem jest funkcjonowanie drogowych szlaków architektury drewnianej w województwie śląskim i opolskim. Oficjalne nazwy szlaków to Szlak Architektury Drewnianej województwa śląskiego i Szlak Drewnianych Kościołów Opolszczyzny.

Zabytkowe obiekty mają zróżnicowany charakter. Wszystkie są obiektami wpisanymi do Rejestru Zabytków, a więc są to obiekty, które mają znaczenie dla dziedzictwa, nie tylko regionu, ale też kraju. Zaletą szlaków jest ich różnorodność. Napotkać tam można nie tylko kościoły ale również chałupy, dzwonnice, kaplice, karczmy, leśniczówki, młyn wodny, skanseny, spichlerze i inne [1]. Cały obszar, na którym rozproszone są poszczególne obiekty w sumie stanowi wielokilometrowe wyzwanie dla osób zainteresowanych odkrywaniem i obcowaniem $\mathrm{z}$ historią $\mathrm{w}$ takiej formie [2].

W ramach działań prowadzonych przez Katedrę Budownictwa Ogólnego i Fizyki Budowli na Wydziale Budownictwa Politechniki Śląskiej prowadzone są liczne prace związane z szeroko rozumianą eksploatacją i utrzymaniem obiektów budowlanych w tym również zabytkowych. Stan techniczny omawianych obiektów Szlaku Architektury Drewnianej lub ich części jest często bardzo zróżnicowany. Istnieje potrzeba nie tylko działań doraźnych mających na celu zachowanie fizycznej substancji obiektów ale również szeregu prac związanych z prowadzeniem opisu stanu technicznego i estetycznego tych obiektów. Prace dotyczą inwentaryzacji obiektów, określenia stanu elementów konstrukcji, wystroju i wyposażenia, określenia parametrów fizykalnych, w tym rozkładu zmian temperatury i wilgotności oraz rozpoznania podstawowych parametrów akustycznych rozpatrywanych obiektów. Działania takie były i są przeprowadzane m.in. w kościołach w Ostropie i Sierotach [3; 4]. Podjęty, pilotażowy program przedstawionych powyżej działań stopniowo ma obejmować kolejne obiekty będące częścią historycznego dziedzictwa Śląska.

Artykuł obejmuje swym zakresem opis działań podjętych celem określenia parametrów akustycznych wnętrz trzech wybranych zabytkowych kościołów drewnianych. Podstawowe informacje o tych obiektach w tym o ich lokalizacji, pełnionej funkcji, obecnym statusie i sposobie użytkowania, zależnościach geometrycznych, danych materiałowych oraz informacje o konstrukcji, zestawiono w tab. 1. Zgromadzone w niej dane są wynikiem przestudiowania opracowań $[5 ; 6 ; 7 ; 8 ; 9 ; 10]$ i wizji lokalnych przeprowadzonych w badanych zabytkach. Rys. 1 przedstawia zdjęcia badanych wnętrz wraz z rozmieszczoną w nich aparaturą badawczą. 


\section{Metodyka prowadzonych pomiarów i obliczeń}

Pomiary akustyczne wraz z wizją lokalną przeprowadzono w kolejności we wszystkich przedstawionych powyżej obiektach (odpowiednio 10.07.2015 r., 11.07.2015 r. oraz 9.05.2015 r.). Badania prowadzono w oparciu o ustalenia i wytyczne zawarte w normie [11]. Zastosowano metodę szumu przerywanego. Zestaw pomiarowy składał się z kuli głośnikowej o dookolnej charakterystyce propagacji dźwięku wraz z generatorem oraz zestawu odbiorczego $\mathrm{w}$ postaci miernika poziomu dźwięku Svan 958 wraz z osprzętem. Źródło dźwięku wytwarzało poziom ciśnienia akustycznego wystarczający do tego, aby krzywa zaniku rozpoczynała się przynajmniej $35 \mathrm{~dB}$ powyżej tła akustycznego w odpowiednim zakresie częstotliwości. W opisywanych badaniach źródło dźwięku umiejscowiono dla kolejnych obiektów w dwu różnych miejscach. Pierwsze umiejscowienie źródła zlokalizowane było w prezbiteriach, przed ołtarzem. Drugie umiejscowienie było przewidziane w nawie głównej. Dla każdego umiejscowienia źródła dźwięku przyjęto po 6 zróżnicowanych umiejscowień mikrofonów pomiarowych jako punktów odbiorczych. W każdym z niezależnych punktów pomiarowych wykonano po 6 powtórzeń pomiarów celem zminimalizowania wpływu losowości sygnału pobudzającego. Schematy pomieszczeń wraz ze sposobem ustawienia źródła dźwięku i mikrofonów pokazano na szkicach zamieszczonych w tab. 1. Oznaczenia od P1K1 do P6K1 obrazują umiejscowienie kolejnych punktów pomiarowych dla pierwszego ustawienia źródła dźwięku natomiast P1K2 do P6K2 dla drugiego ustawienia. Zarówno umiejscowienie źródeł dźwięku jak i punktów pomiarowych spełniało minimalne wytyczne normowe co do odległości od powierzchni odbijających i odległości punktów pomiarowych w stosunku do źródła dźwięku. Na podstawie uzyskanych wyników pomiarów dokonano wyznaczenia czasów pogłosu T20. Zmierzone krzywe zaniku dźwięku oceniano w zakresie od $5 \mathrm{~dB}$ do $25 \mathrm{~dB}$ poniżej ustalonego poziomu dźwięku. Wyniki w postaci charakterystyk częstotliwościowych czasu pogłosu przedstawiono w opracowaniu w formie graficznej.

\section{Wyniki pomiarów i podsumowanie}

Porównanie uśrednionych czasów pogłosów trzech zbadanych pomieszczeń w funkcji częstotliwości zobrazowano na rys. 2. Poniższe wartości uzyskano w wyniku uśrednienia zmierzonych czasów pogłosów w poszczególnych punktach pomiarowych dla kolejnych pomiarów w punkcie i kolejnych ustawień kuli głośnikowej. Ponadto na wykres naniesiono obszar przyjmowanego zakresu tolerancji dla czasów pogłosu w funkcji częstotliwości. W artykule przywołano niektóre z wyznaczonych na podstawie badań czasu pogłosu cech obrazujących szerzej charakter akustyczny rozpatrywanych wnętrz. Wskaźnik zrozumiałości mowy STI wyznaczono w oparciu o [12], pozostałe na podstawie [13]. 
Tabela 1. Zestawienie podstawowych informacji o rozpatrywanych obiektach

Table 1. Sheet of bases information about considering objects

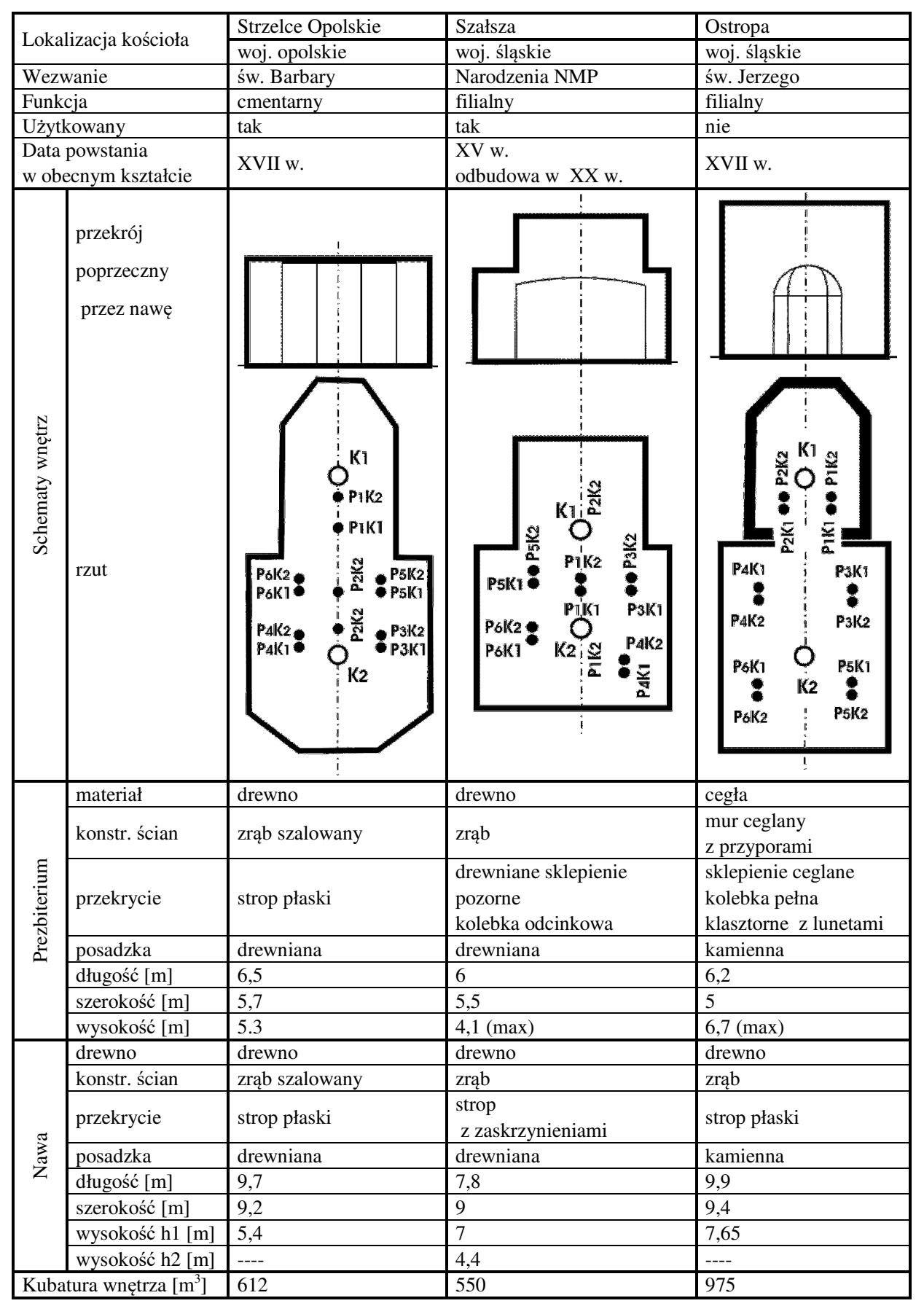




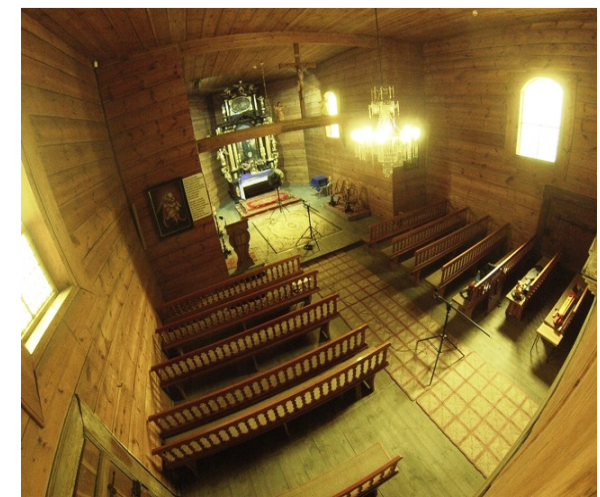

a)

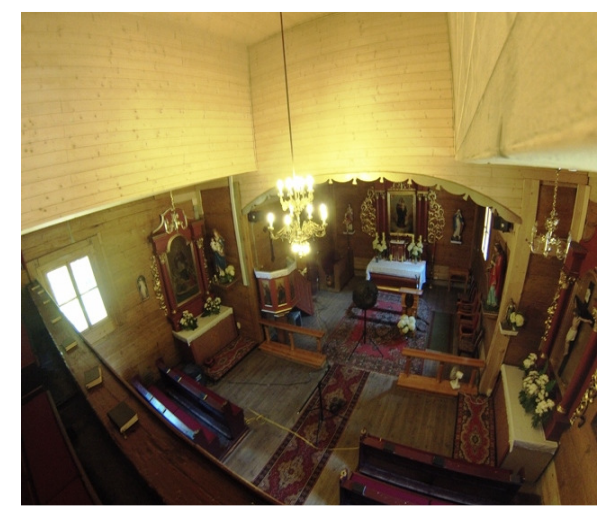

c)

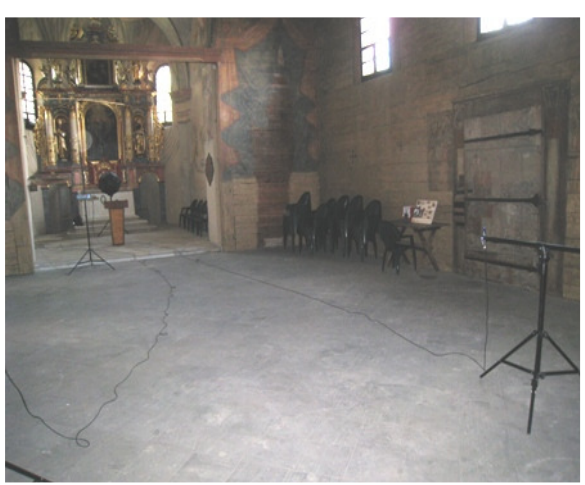

e)

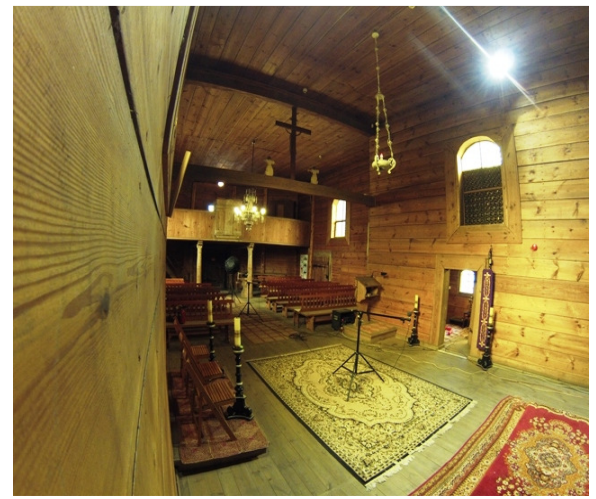

b)

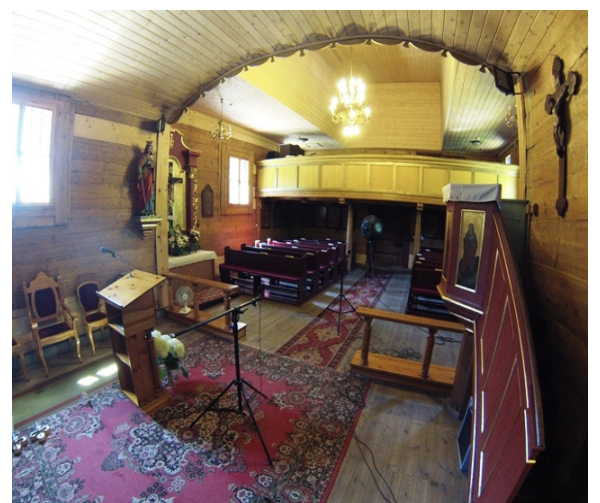

d)

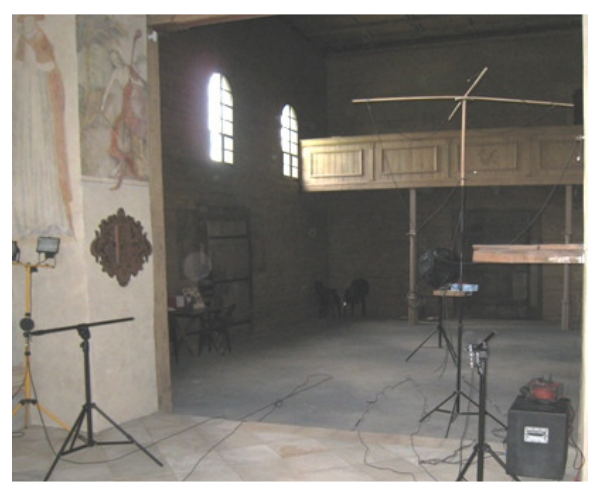

f)

Rys. 1. Wnętrza badanych kościołów: św. Barbary w Strzelcach Opolskich (a, b); Narodzenia NMP w Szałszy (c, d) i św. Jerzego w Ostropie (e, f)

Fig. 1. Interiors of investigating churches: Saint Barbara's in Strzelce Opolskie (a, b); Birth Blessed Virgin Mary's in Szałsza (c, d) and Saint George's in Ostropa (e, f) 


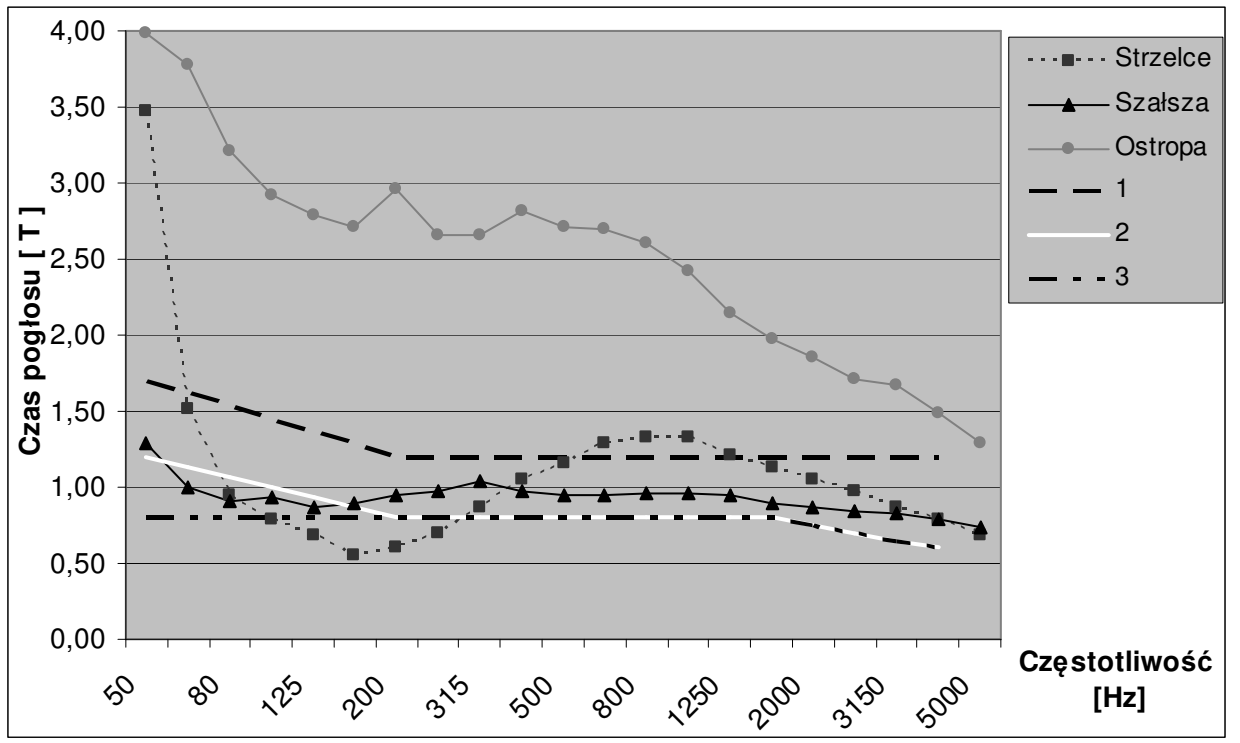

Rys. 2. Uśrednione wartości czasów pogłosu w funkcji częstotliwości dla rozpatrywanych obiektów. 1 do 2 - obszar tolerancji czasów pogłosu dla dźwięku muzycznego, 1 do 3 - obszar tolerancji czasów pogłosu dla słowa mówionego

Fig. 2. Average values of reverberation times as a frequency function for considering churches. 1 to 2 - area of reverberation's time tolerance for musical sound. 1 to 3 - area of reverberation's time tolerance for verbalized sound

Średni czas pogłosu dla badanych pomieszczeń kształtował się dla kościoła w Strzelcach Opolskich na poziomie 1,09 s, dla kościoła w Szałszy 0,93 s oraz 2,55 s dla kościoła w Ostropie. Przebieg wartości czasów pogłosu w funkcji częstotliwości dla kościoła w Ostropie wydaje się być dość charakterystyczny dla pomieszczeń o stosunkowo pustym wnętrzu, podobnym kształcie, kubaturze. Obecnie wykonany pomiar różni się tylko nieznacznie od przeprowadzonego w 2008 roku jeśli chodzi o średnie wartości czasu pogłosu. Inny jest jednak przebieg krzywej czasów pogłosu dla częstotliwości niskich. W wyniku działań konserwatorskich w stosunku do warunków pomiarowych z 2008 roku zmieniony został sufit przykrywający nawę główną, a także odnowiono powierzchnie ołtarza w prezbiterium. Długi czas pogłosu ulegnie skróceniu w związku ze stopniowym zapełnianiem wnętrza elementami wyposażenia wraz z przywracaniem normalnej funkcji użytkowej kościoła.

Najbardziej równomierny rozkład czasu pogłosu można zaobserwować dla krzywej reprezentującej kościół w Szałszy. Płaski przebieg tej krzywej dla niskich i średnich częstotliwości owocuje tzw. stosunkiem basów na poziomie 0,97 , co przekładać się może pozytywnie na cechę określaną jako ciepło brzmienia. Ze względu na charakter wnętrza (użytkowany kościół) krótki, średni czas pogłosu nie do końca predestynuje to wnętrze do odbioru muzyki (w tym 
liturgicznej organowej - kościół wyposażony jest w działające organy). W zakresie niskich częstotliwości czas pogłosu nieco wykracza poza przyjęte optimum.

Z drugiej strony może to oznaczać dobre warunki do odbioru słowa mówionego. Wstępnie określony wskaźnik zrozumiałości mowy dla tego wnętrza przyjmuje wartość około 0,66. Przekłada się to w ogólnej klasyfikacji na ocenę dobry z zakresu od zły do doskonały. Cecha określana jako klarowność kształtuje się dość równomiernie dla całego rozpatrywanego zakresu częstotliwości i przyjmuje wartości z zakresu 3-4 $\mathrm{dB}$. Wskazuje to na dobrą dla takiego wnętrza rozróżnialność dźwięków i ich pochodzenia.

Krzywa obrazująca uśrednione wartości czasu pogłosu dla wnętrza kościoła w Strzelcach Opolskich przyjmuje dość ciekawy układ. Zastanawiające jest znaczne obniżenie czasów pogłosu dla częstotliwości pomiędzy około 125 a $315 \mathrm{~Hz}$. Uzyskane wyniki są znacznie niższe niż dla częstotliwości średnich. Taki przebieg krzywej skutkuje znacznie obniżonym stosunkiem basów $(0,55)$. Jednocześnie klarowność dla zakresu niskich częstotliwości jest duża. Średnio cecha ta przyjmuje wartość około $3,8 \mathrm{~dB}$. Jest to wynik podobny do uzyskanego w kościele w Szałszy.

Przeprowadzone do tej pory badania wskazują na celowość dalszych działań mających na celu zobrazowanie szeregu parametrów fizykalnych w tym związanych z akustyką dla rozpatrywanego zasobu obiektów zabytkowych.

Opracowano w Politechnice Ślaskiej w ramach pracy BKM-504/RB3/2015.

\section{Literatura}

[1] Ruszczyk G.: Architektura drewniana w Polsce. Muza, Warszawa 2009.

[2] http://www.slaskie.pl/sad/ \{dostęp 5.05.2016 r.\}.

[3] Kościół św. Jerzego. Ostropa, z serii: Spotkanie z Zabytkiem. Monografia. ISSN 1898-7168; R. (II) 2008, nr 1, Majewski S. (red.), Wydział Budownictwa Politechniki Śląskiej, Gliwice.

[4] Marchacz M. Dulak L.: Badania akustyczne wnętrza zabytkowego kościoła pw. Wszystkich Świętych w Sierotach. Czasopismo Inżynierii Lądowej, Środowiska i Architektury - Journal of Civil Engineering, Environment and Architecture, JCEEA, t. XXXI, z. 61 (3/II/14), 2014, s. 339-346, DOI:10.7862/rb.2014.100.

[5] Chrzanowski T., Kornecki M.: Sztuka Śląska Opolskiego; Od średniowiecza do końca w. XX. Wydawnictwo Literackie, Kraków 1974, s. 424.

[6] Żaba A. (red.): Projekt Strzelce Opolskie_2014: Kościół cmentarny pw. św. Barbary. Opracowanie studentów specjalności N2_IPB_EOB, Gliwice: Wydział Budownictwa Politechniki Śląskiej, Gliwice 2014, (opracowanie niepublikowane).

[7] Gadomski S.: Drewniane kościoły województwa śląskiego. Italis, Chorzów 2001, s. 44.

[8] Żaba A. (red.): Projekt Szałsza_2015: Kościół Narodzenia Najświętszej Marii Panny. Opracowanie studentów specjalności S1_CKI_AB, Wydział Budownictwa Politechniki Śląskiej, Gliwice 2015, (opracowanie niepublikowane). 
[9] Żaba A. (red.): Projekt Ostropa_2015: Kościół pw. św. Jerzego w Ostropie. Opracowanie studentów specjalności S1_CKI_BA, Wydział Budownictwa Politechniki Śląskiej, Gliwice 2015, (opracowanie niepublikowane).

[10] Żaba A. Restytucja stropu nawy kościoła pw. św. Jerzego w Ostropie i jego polichromii. W: Malowidła kościoła św. Jerzego. Ostropa, z serii: Spotkanie z Zabytkiem. Monografia. ISSN 1898-7168; R. (V) 2011, nr 4, Majewski S. (red.): Wydział Budownictwa Politechniki Śląskiej, Gliwice, s. 113-125.

[11] PN-EN ISO 3382-2:2010 - Akustyka - Pomiar parametrów akustycznych pomieszczeń - Część 2: Czas pogłosu w zwyczajnych pomieszczeniach.

[12] Nowoświat A.: Model logarytmiczny wyznaczania wskaźnika zrozumiałości mowy. W: Materiały z konferencji Fizyka Budowli w Teorii i Praktyce, tom 2, Łódź 2007, s. $215-218$.

[13] Springer Handbook of Acoustics: Charter 9, s. 308-310. e-ISBN: 0-387-30425-0.

\title{
PRELIMINARY ACOUSTIC INVESTIGATIONS OF THE WOODEN HISTORIC CHURCHES ON THE UPPER SILESIA AREA
}

\begin{abstract}
S u m m a r y
The paper presents acoustic investigations of selected wooden monumental churches which are part of material cultural heritage. Selected objects belong to areas of Silesian province and Opole province. Their placing are connected with both Upper Silesian wooden architecture routes. Contained in route's area objects it's not only churches but also shanties, belfries, chapels, taverns, forester lodges, water mill, antique building museums, garners. Investigated in paper objects, it is Saint Barbara's church in Strzelce Opolskie, Birth Blessed Virgin Mary's church in Szałsza and Saint George's church in Ostropa. Acoustic measurements of interiors was realized as a part of broader series of works concerning issues connected with operation and maintenance historic objects. The paper contains in introduction historic basic description for presenting object with short information about construction. In the next part was shown measurement methodology linked with reverberation time's determining for interiors of considering objects. Reverberation time is presenting as a main acoustic parameter describing investigated interiors. Based on the standards, a number of acoustic measurements were done. This measurements were a base for evolving of reverberation time's characteristics as function of frequency and average values of reverberation time for each of the measurement points in each of considering interiors. Showed reverberation time characteristics as a function of frequency and average values were a starting point to further evaluation of acoustic quality for considering interiors. In resume of this work showed discussion about selected acoustic criterions of acoustic evaluation for interiors based on measurements results.
\end{abstract}

Keywords: Interior acoustics, reverberation time, measurements of reverberation time, historic wooden architecture

DOI: $10.7862 / \mathrm{rb} .2016 .208$

Przestano do redakcji: $30.06 .2016 r$.

Przyjęto do druku: $30.11 .2016 r$. 